\title{
THE EXCHANGEABLE POTASSIUM CONTENT OF NORMAL WOMEN ${ }^{1,2}$
}

\author{
BY JERRY K. AIKAWA,3 GEORGE T. HARRELL, AND BERNARD EISENBERG \\ (From the Department of Internal Medicine, Bouman Gray School of Medicine of Wake Forest \\ College, Winston-Salem, North Carolina)
}

(Submitted for publication September 17, 1951; accepted February 1, 1952)

A method, utilizing a radioactive isotope $\left(\mathrm{K}^{\mathbf{4 2}}\right)$, for the measurement of the exchangeable potassium content of the body has been recently reported (1). That study was performed on a relatively homo-. geneous group of 30 young male subjects. Because of differences in physical characteristics and endocrine functions, the relative body potassium content in the two sexes might be dissimilar. The normal range in healthy young women has not been established. In the present study, the exchangeable potassium content in a homogeneous group of 20 healthy young adult women was determined and an attempt was made to correlate it with body weight and urinary creatinine excretion.

\section{MATERIAL AND METHODS}

The subjects were 20 healthy nurses, medical students, and laboratory technicians between the ages of 19 and 32 years. They were ambulatory and continued with their usual activities during the period of the study. Two groups consisting of nine and 11 individuals were studied two weeks apart. The subjects were in various stages of their menstrual cycle.

Experimental procedure: Each subject was given an intravenous injection of radioactive potassium ${ }^{4}$ by calibrated syringe in the morning between 6:30 and 9:00 a.m. All urine specimens until 7:00 a.m. the next morning were collected and pooled, and this collection of urine was measured for the excretion of $\mathrm{K}^{23}$. Specific activity of the urine was determined on two spot samples collected at 8:00 and 9:00 a.m. on the day after injection. Preliminary studies confirmed the observations of Corsa and associates (1) that the specific activity of $\mathrm{K}^{\text {sa }}$ in the urine had reached an equilibrium by 24 hours. No restrictions were placed on activity or on the intake of food, water or salt.

\footnotetext{
1 This work was supported (in part) by the U. S. Atomic Energy Commission under a contract with the Bowman Gray School of Medicine and (in part) by a research grant from the American Heart Association.

2 Technical assistance by Miss Eloise Rhoades is gratefully acknowledged.

3 Research Fellow of the American Heart Association.

$\leqslant$ The $\mathrm{K}^{\text {s }}$ used was supplied by the National Laboratory, Oak Ridge, Tennessee, on allocation from the U. S. Atomic Energy Commission.
}

Preparation and administration of radioactive potassium: The shipments of $\mathrm{K}^{12}$ were treated in the manner described by Corsa and his co-workers (1). One and a half milliequivalents of potassium chloride solution, containing 100 microcuries of $\mathrm{K}^{\mathbf{4 2}}$, were injected intravenously.

Measurement of radioactivity: The activity of the urine specimens was determined with a dipping tube and a scaling circuit. Counts were made to $1 \%$ accuracy. All counting rates were at least ten times background, and were usually in the range of 500 to 3,000 per minute. At these counting rates, no correction for coincidence was necessary. All determinations were corrected for decay.

Chemical determinations: The total potassium concentration in the urine was determined by flame photometry, using a method which has been described previously (2). Urinary creatinine concentration was determined by the method of Bonsnes and Taussky (3).

Calculation of exchangeable potassium: The following formula was used to calculate the value for the exchangeable potassium content of the body:

$$
K_{0}=\frac{K_{1}^{12}-K_{0} 18}{\frac{K_{u^{12}}}{K_{u^{29}}}}
$$

$\mathrm{K}_{0}=$ quantity of exchangeable potassium in milliequivalents.

$\mathrm{K}_{1}{ }^{12}=$ quantity of radiopotassium administered (arbitrary units).

$\mathrm{K}_{0}{ }^{12}=$ quantity of radiopotassium excreted in the urine in the pooled specimen.

$\mathrm{K}_{\mathbf{u}} \mathbf{1 2}^{2}=$ concentration of radiopotassium in the urine samples.

$\mathrm{K}_{\mathrm{u}}{ }^{42} / \mathrm{K}_{\mathrm{u}}{ }^{30}=$ mean specific activity of two spot specimens.

\section{RESULTS}

The measurements are summarized in Table I. The mean value for the $K_{e}$ was 1776 meq. with a standard deviation of 229 . The mean value for $\mathrm{K}_{\mathrm{e}} / \mathrm{Wt}$. was $31.5 \mathrm{meq} . / \mathrm{Kg}$. with a standard deviation of 2.9. Although there was a considerable latitude in the values for $K_{e}(1374-2164$ meq. $)$ and $\mathrm{K}_{\mathrm{e}} / \mathrm{Wt}$. (25.1 - 35.9 meq./Kg.), these ranges were less than those reported in normal young males (1). A slight correlation was found by visual inspection between $\mathrm{K}_{\mathrm{e}}$ to $\mathrm{Wt}$., $\mathrm{K}_{\mathrm{e}} / \mathrm{Wt}$. to creatinine coefficient (Figure 1 ), and $K_{e}$ to creatinine. Calculation of the data in relation to surface area, which would tend to correct out the variation 
TABLE I

Exchangeable potassium content of normal young adult women

\begin{tabular}{|c|c|c|c|c|c|c|c|c|c|}
\hline \multirow{2}{*}{ Subjects } & \multirow{2}{*}{$\underset{\text { Age }}{\text { (yrs.) }}$} & \multirow{2}{*}{$\begin{array}{c}\text { Height } \\
\text { (cm.) }\end{array}$} & \multirow{2}{*}{$\begin{array}{c}\text { Exchangeable } \\
\text { potassium } \\
\text { (meq.) }\end{array}$} & \multirow{2}{*}{$\begin{array}{c}\text { Ranget } \\
(\% \text { of mean) }\end{array}$} & \multirow{2}{*}{$\begin{array}{l}\text { Weight } \\
\text { (Ke.) }\end{array}$} & \multirow{2}{*}{$\underset{\left(m e q . / \mathbf{K}_{\mathbf{l}}\right)}{\left.\mathbf{K}_{\mathbf{l}} / \mathbf{W t}\right)}$} & \multirow{2}{*}{$\begin{array}{l}\mathbf{K}^{\oplus} \\
\text { Excretion } \\
\text { (\% dose) }\end{array}$} & \multicolumn{2}{|c|}{ Creatinine } \\
\hline & & & & & & & & (ms./Kg.) & (mg.) \\
\hline 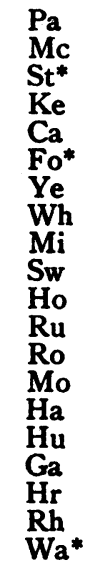 & $\begin{array}{l}26 \\
24 \\
25 \\
23 \\
21 \\
25 \\
19 \\
24 \\
25 \\
32 \\
21 \\
21 \\
23 \\
32 \\
23 \\
22 \\
24 \\
25 \\
23 \\
25\end{array}$ & $\begin{array}{l}171 \\
171 \\
171 \\
170 \\
166 \\
170 \\
170 \\
163 \\
173 \\
163 \\
169 \\
170 \\
168 \\
163 \\
160 \\
159 \\
163 \\
157 \\
166 \\
157\end{array}$ & $\begin{array}{l}2,164 \\
2,087 \\
2,055 \\
2,034 \\
1,993 \\
1,989 \\
1,959 \\
1,909 \\
1,786 \\
1,721 \\
1,677 \\
1,675 \\
1,648 \\
1,647 \\
1,630 \\
1,589 \\
1,563 \\
1,524 \\
1,489 \\
1,374\end{array}$ & $\begin{array}{r}8.87 \\
9.67 \\
0.92 \\
0.49 \\
2.40 \\
2.80 \\
3.87 \\
2.93 \\
19.50 \\
2.55 \\
4.20 \\
9.61 \\
6.70 \\
15.60 \\
4.41 \\
8.50 \\
11.80 \\
0.85 \\
19.80 \\
0.80\end{array}$ & $\begin{array}{l}62.7 \\
60.9 \\
59.1 \\
61.4 \\
55.1 \\
61.4 \\
56.4 \\
60.9 \\
59.1 \\
68.6 \\
48.6 \\
60.5 \\
53.2 \\
50.9 \\
55.5 \\
54.5 \\
55.9 \\
47.0 \\
48.6 \\
47.3\end{array}$ & $\begin{array}{l}34.5 \\
34.3 \\
34.8 \\
33.1 \\
35.9 \\
32.4 \\
34.7 \\
31.3 \\
30.2 \\
25.1 \\
34.5 \\
27.7 \\
31.0 \\
32.4 \\
29.4 \\
29.2 \\
28.0 \\
32.4 \\
30.6 \\
29.0\end{array}$ & $\begin{array}{l}3.11 \\
4.20 \\
4.10 \\
2.90 \\
4.00 \\
4.92 \\
3.59 \\
2.36 \\
2.63 \\
4.83 \\
3.19 \\
2.81 \\
3.40 \\
5.39 \\
2.02 \\
4.43 \\
2.45 \\
2.79 \\
3.68 \\
3.61\end{array}$ & $\begin{array}{l}22.3 \\
20.5 \\
22.0 \\
21.6 \\
22.7 \\
23.3 \\
12.8 \\
28.6 \\
24.1 \\
18.4 \\
22.5 \\
17.1 \\
21.7 \\
21.5 \\
21.8 \\
23.4 \\
21.6 \\
22.9 \\
29.2 \\
23.0\end{array}$ & $\begin{array}{r}1,400 \\
1,248 \\
1,300 \\
1,322 \\
1,250 \\
1,431 \\
718 \\
1,739 \\
1,427 \\
1,261 \\
1,092 \\
1,034 \\
1,154 \\
1,094 \\
1,209 \\
1,273 \\
1,208 \\
1,095 \\
1,420 \\
1,088\end{array}$ \\
\hline $\begin{array}{l}\text { Mean } \\
\text { Range }\end{array}$ & $\begin{array}{c}24.2 \\
19-32\end{array}$ & $\begin{array}{c}166 \\
157-173\end{array}$ & $\begin{array}{c}1,776 \\
1,374-2,164\end{array}$ & $\begin{array}{c}6.81 \\
0.49-19.80\end{array}$ & $\begin{array}{c}56.4 \\
47.0-68.6\end{array}$ & $\begin{array}{c}31.5 \\
25.1-35.9\end{array}$ & $\begin{array}{c}3.52 \\
2.02-5.39\end{array}$ & $\begin{array}{c}22.0 \\
12.8-29.2\end{array}$ & $\begin{array}{c}1,237 \\
718-1,739\end{array}$ \\
\hline
\end{tabular}

* The menstrual period had just started in these three individuals when this study was made.

$\uparrow$ Range of exchangeable potassium values based on urine specific activities, as \% of the mean.

due to obesity, did not result in better correlation of $\mathrm{K}_{\mathrm{e}}$ to creatinine.

\section{DISCUSSION}

The women in the present study were of an age group comparable to that of men investigated by Corsa and associates (Table II). The men were roughly $12 \mathrm{~cm}$. taller and $16 \mathrm{Kg}$. (approximately $30 \%$ ) heavier. The most striking difference between the two sexes was in the mean value for $\mathrm{K}_{\mathrm{e}} / \mathrm{Wt}$., which, in the females, was $2 / 3$ of that found in males. This difference is apparently due to the greater relative fat content in women. The high range of the creatinine coefficient indicates

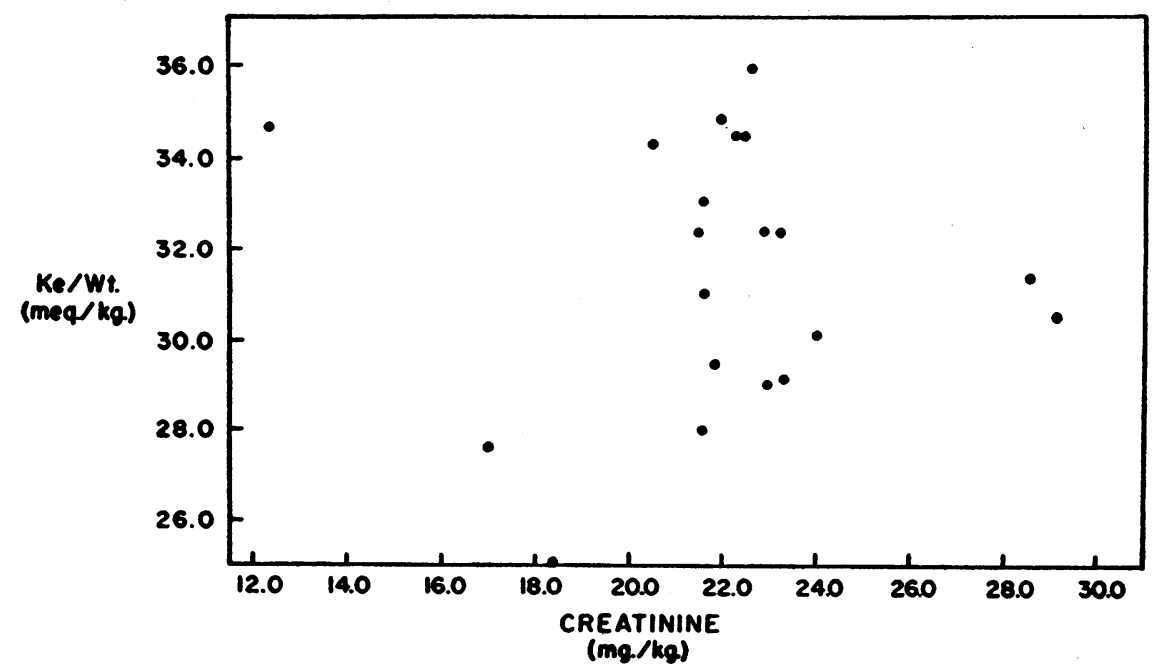

Fig. 1. Correlation Between Exchangeable Potassium Content and Creatinine Excretion in Normal Young Adult WoMren 
TABLE II

Exchangeable potassium content of normal young adult males (1)

\begin{tabular}{|c|c|c|c|c|c|c|}
\hline & $\begin{array}{c}\text { Age } \\
\text { (yrs.) }\end{array}$ & $\begin{array}{c}\text { Height } \\
\text { (cm.) }\end{array}$ & $\begin{array}{l}\text { Exchange- } \\
\text { able } \\
\text { potassium } \\
\text { (meg.) }\end{array}$ & $\begin{array}{l}\text { Weight } \\
\left(\mathbf{K}_{\mathbf{g}}\right)\end{array}$ & $\underset{\left(\mathbf{m e q} . / \mathbf{K}_{\boldsymbol{g}}\right)}{\mathbf{K}_{0} / \mathbf{W t}}$ & $\begin{array}{c}\text { Creati- } \\
\text { nine } \\
\text { (ms.) }\end{array}$ \\
\hline $\begin{array}{l}\text { Mean } \\
\text { Range }\end{array}$ & $\begin{array}{c}25.8 \\
21-30\end{array}$ & $\begin{array}{c}177.5 \\
162-198\end{array}$ & $2,770-4,470$ & $\begin{array}{c}72.6 \\
57.0-125.5\end{array}$ & $\begin{array}{c}46.3 \\
35.6-53.6\end{array}$ & $1.724^{*}$ \\
\hline
\end{tabular}

All values are based on determinations in 30 subjects.

* Mean of five determinations.

the variability in their relative muscle mass. The lack of correlation between $\mathrm{K}_{e}$ and creatinine in women indicates the variability in the proportion of potassium containing tissues other than muscle to muscle mass among individuals of this sex.

It is recognized that an incomplete urine collection may lead to a false low creatinine excretion and a false high $\mathrm{K}_{\mathrm{e}}$. In the present study this error is considered to be minimal, since all subjects were cooperative volunteers. In men, there appears to be a good correlation between $K_{e}$ and urinary creatinine excretion, so that a fair estimate of $\mathrm{K}_{\mathbf{e}}$ is possible from the latter measurement. Such apparently is not the case in females. It is possible that a more detailed study of a larger series of women with due considerations for the variations in age, body build, and the stage of the menstrual cycle may establish a closer correlation of $K_{e}$ with other anthropometric measurements. It would appear, from the data to date, that in any study in women, the definition of alterations in the exchangeable potassium content of the body should depend on serial determinations in the same individual.

\section{SUMMARY}

The mean exchangeable potassium content in a homogeneous group of 20 normal young women was found to be $31.5 \mathrm{meq} . / \mathrm{Kg}$. This value was considerably lower than the value in normal young men. Only slight correlation was found with body weight or urinary creatinine excretion.

\section{REFERENCES}

1. Corsa, L., Jr., Olney, J. M., Steenburg, R. W., Ball, M. R., and Moore, F. D., The measurement of exchangeable potassium in man by isotope dilution. J. Clin. Invest., 1950, 29, 1280.

2. Aikawa, J. K., Fluid volumes and electrolyte concentrations in normal rabbits. Am. J. Physiol., 1950, $162,695$.

3. Bonsnes, R. W., and Taussky, H. H., On the colorimetric determination of creatinine by the Jaffe reaction. J. Biol. Chem., 1945, 158, 581. 